\title{
Diskursi feminizma i modernizma u esejima Julke Chlapec Đorđević i Jele Spiridonović-Savić
}

\begin{abstract}
Dubravka, Diskursi feminizma i modernizma u esejima Julke Chlapec Đorđević i Jele Spiridonović-Savić (Discourses of Feminism and Modernism in the Essays of Julka Chlapec Đorđević and Jela Spiridonović-Savić). „Poznańskie Studia Slawistyczne” 6. Poznań 2014. Publishing house Science and Innovate, pp. 327-340. ISBN 978-83-63795-51-1. ISSN 2084-3011.

I start from the definition of Serbian Yugoslav bourgeois culture as a semi-peripheral and having this in mind, I tend to analyze the essays by Julka Chlapec Đorđević and Jela Spiridonović-Savić, from the perspective of the world systemic theories applied to literature.
\end{abstract}

Keywords: anti-modernism; feminism; modernism; semi-periphery

\section{Prethodna napomena}

Pod uticajem teorija globalizacije u teoriji književnosti se od kraja 90-ih godina 20. stoleća razvijaju sistemski pristupi u proučavanju književnosti. Za moj rad posebno je značajna knjiga Pascale Casanova The World Republic of Letters, jer metodologiju koju je razvila primenjujem u razmatranju eseja Julke Chlapec Đorđević i Jele Spiridonović-Savić. Odbacujem pristup metodološkog nacionalizma, usredsređenog na nacionalnu kulturu kao homogenu organsku celinu koju združuje nacionalna pripadnost protagonista, zajednički jezik ili teritorijalne granice i primenjujem metodološki kosmopolitizam, kojim želim pokazati da se kulturalni fenomeni u određenom lokalnom kontekstu ne dešavaju spontano i izolovano u odnosu na globalne scene, već da su kulturalni modeli globalni, putujući i da se u lokalnim kulturama glokalizuju (Đurić 2013). Dakle, zanimaće me odnos

* Rad je nastao u okviru projekta br. 178029 Ministarstva za prosvetu i nauku Srbije. 
globalno-lokalno. Moja interpretacija nije izvedena iz trenutno popularnih studija Jugoslavije, te me neće zanimati da eseje autorki postavim u kontekst Kraljevine Jugoslavije, poredeći njihove ideje sa idejama njihovih savremenika i savremenica. Pa ipak, instistirajući da njihov rad pripada srpskoj jugoslovenskoj buržaoskoj kulturi, želim ih postaviti u kontekst multikulturnalne buržoaske Jugoslavije. Ovu odrednicu koristim indeksno, jer, mada se time ne bavim, želim istaći da jugoslovenske nacionalne buržoaske kulture nisu nastajale u međusobnoj izolaciji, kao i da nije nevažno da li se autorski opus realizovao u buržoaskoj ili socijalističkoj jugoslovenskoj kulturi. Primenjujući sistemsku analizu P. Casanove, naglasak u tekstu je na tome kako se globalni hegemoni modeli modernizma i feminizma artikulišu u esejima izabranih autorki. Pojmovi središnji, poluperiferni i periferni su mi važni jer govore o ekonomskom i kulturalnom kapitalu koji jedna zemlja može da stekne, a koji je determinisan njenim mestom u svetskom sistemu, koji određuju procesi kolonijalizma, dekolonijalizacije, neokolonijalizacije. I mada je pristup P. Casanova izložen brojnim kritikama, još uvek mnogi, među kojima sam i ja, nalaze da on omogućava zanimljive nove interpretacije kulturnih fenomena u određenim lokalnim kontekstima.

\section{Pozicioniranje srpske jugoslovenske buržoaske kulture kao poluperiferne}

Ovim tekstom bih želela da na globalnu scenu postavim malu poluperifernu srpsku jugoslovensku buržoasku kulturu između dva svetska rata, baveći se esejima Julke Chlapec Đorđević i Jele Spiridonović-Savić. Danas se poluperiferne i periferne kulture konceptualizuju pojmovima alternativni ili multiplicirani moderniteti. Nekada se smatralo da modernitet počiva na „osnovnoj razlici između društvenih formacija «Zapada» $\mathrm{i}$ «tradicionalnih» ili «predmodernih» društava" (Bhambra 2007: 3). Poslednje dve decenije pokazuju da se teorije o alternativnim, globalnim, hibridnim i složenim modernitetima umnožavaju, da bi se otišlo dalje od ograničenog evropocentričnog razumevanja sveta. Smatra se da ne postoji singularnost moderniteta, zasnovanog na tradicionalnijem, pravolinijskom, istorijskom razumevanju, već se raspravlja o multipliciranim modernostima. 
Korisna je teorija svetskog sistema i njena primena u razmatranju svetske književnosti. Pascale Casanova je pisala da ,iako je temeljno povezano sa razvojem moderne nacionalne države, polje književnosti nije jedinstveno determinisano političkom istorijom, već uspostavlja sopstveni odvojeni sistem odnosa moći” (Casanova 2004: 191). Formiranje država i pojavljivanje književnosti u novim jezicima proizlazi iz jedinstvenog principa diferencijacije. U ovom narativu, politički i književni prostor nastaju istovremeno, sa paradoksalnim rezultatom rođenja književnosti koja izrasta iz rane političke istorije nacionalne države. Posmatrajući države i kulture sa aspekta teorija globalizacije, Marko Juvan piše o transnacionalnoj ideologiji nacionalizma (Juvan 2009: 192), a Casanova naglašava da nijedan nacionalni entitet ne postoji po sebi i za sebe i da ništa nije internacionalnije od nacionalne države, jer je konstruisana samo u odnosu na druge države, često u suprotnosti sa njima. Koristeći teoriju svetskog sistema Immanuela Walersteina, Juvan je pisao da se pri globalnom širenju univerzalne logike kapitalistička svetska ekonomija susrela sa raznolikim društvima, jezicima, kulturama i vrednosnim sistemima. Ukrštanja tih partikularnih društava s univerzalnim ekonomskim principima, posvetovljeni kapitalizam je, po Wallersteinu, pokušao razrešiti ,izvozom” i rasprostiranjem modela nacionalnih država, koje su se nakon Vestfalskog mira počele povezivati u ,međudržavni sistem” i razvijanjem ,geokulture”, tj. globalnim širenjem istih kulturnih uzoraka društvenog uređenja, vrednosnih sistema, ideologija, životnih navika i stilova, teorije i umetnosti (Juvan 2009: 191).

Za naše razmatranje bitna je Wallersteinova podela država po društvenoekonomskoj, političkoj i vojnoj moći, na centralne (jezgrene) i rubne države i između njih smeštene ,,poluperiferije”. Za svetski sistem kapitalizma bitno je da jedan broj država dominira, a ostale od njih manje ili više zavise. Ali pored velikih centara središnjih zemalja, poput Francuske, Engleske, Nemačke, Italije i Sjedinjenih Američkih Država, poluperiferne evropske kulture imaju svoje centre prema kojima se odnose kao periferije.

U ovom kontekstu, srpsku buržoasku jugoslovensku kulturu smeštam među poluperiferne kulture (Đurić 2011). Da bi se razumela specifična pozicija poluperiferije, pozvaću se na Marinu Blagojević, koja je konstatovala da je poluperiferija mesto iz-među, i to iz-među je uslov njenog postojanja. Ona se razlikuje kako od jezgra tako i od periferije (Blagojević 2009: 74). Poluperiferija uvek kasni za centralnim zemljama, u njoj se razvija žudnja 
za Zapadom ali i otpor prema Zapadu. U trenutku kada su Chlapec Đorđević i Spiridonović-Savić delovale između dva svetska rata, srpska buržoaska jugoslovenska kultura kao poluperiferna, bila je relativno stabilno okrenuta Zapadu. U izvesnoj meri je uhvatila korak sa razvijenim zemljama centra. Emancipatorski diskursi modernizma i feminizma aktivirani u njihovim esejima deo su ,žudnje za Zapadom”, tj. težnje da se jedna nerazvijena (polu)periferna evropska kultura priključi razvijenom zapadnom svetu. I mada govorim o srpskim autorkama, imam na umu da je širi državni i kulturni kontekst njihovog delovanja bila multikulturalna Kraljevina Jugoslavija, u kojoj su jugoslovenske kulture, srpska kao hegemona ${ }^{1}$, a zatim hrvatska i slovenačka, participirale u konstruisanju jugoslovenske kulture, ali je postojala i stalna tenzija i rivalstvo između njih.

\section{Feministička sociologija i feministička književna kritika Julke Chlapec Đorđević}

Julka Chlapec Đorđević je veći deo života provela u češkoj kulturi, poluperifernoj u odnosu na zemlje jezgra, ali naprednijoj u odnosu na jugoslovenske kulture (vrhunac modernizacije je u Češkoj završen pre nego što je u Srbiji i kasnije u Jugoslaviji započeo), te se postavila kao jedno od središta poluperiferije. U recenziji knjige Studije i eseji o feminizmu Ksenija Atanasijević je 1936. pisala da ,g-đa dr Hlapec ima i to preimućstvo što živi u Pragu, - centru gde pojam feminizma nikad nije bio samo prazna shema..." (Atanasijević 2008: 199). Povodom knjige Kriza seksualne etike, Atanasijević je istakla da je „domaća feministička literatura sasvim oskudna, kad se uporedi sa onima zemljama severne i zapadne Evrope i Amerike" i ističe da naša sredina ,nije mnogo pogodna da se u njoj i za nju podižu i brane dokazi i nauči kako ženu treba postaviti na plan slobodnog ljudskog individuuma" (Atanasijević 2008: 194). U esejima o feminizmu Chlapec Đorđević je: 1) gotovo enciklopedijski mapirala diskurse o ženi i ženskosti. Razlog za to je želja da se ispuni ,praznina” u matičnoj (polu)perifernoj kulturi, i da se ona istovremeno simbolički uvede u internacionalni diskurs

1 Hegemonija srpske kulture se izvodi iz činjenice da se zemlja ujedinila i oformila pod srpskom dinastijom Karađorđević (a i Srbi su bili u novoosnovanoj državi najbrojnija etnička grupa). 
zapadne kulture, kojoj srpska, odnosno jugoslovenska, kultura između dva svetska rata (teži da) pripada; 2) ona pokazuje da je polje diskursa o ženi i ženskosti bojno polje u kojem se diskursi razvijeni u različitim naučnim poljima sukobljavaju u borbi za prevlast u definisanju diskurzivnih pozicija koje mogu zauzimati žene; 3) opisujući detaljno ove diskurse, ona konstruiše sopstvenu kritičku poziciju, kojoj je višeglasje tih diskursa potrebno da bi se odredila kao ekspertkinja koja: a) živi između nekoliko poluperifernih evropskih kultura, koje uspostavljaju međusobni hijerarhijski odnos, mada su u odnosu na jezgrene kulture na poziciji margine, dok poluperiferna kultura kojoj matično pripada usled kasnog stupanja u svetski sistem država, nema dovoljno intelektualnog resursa i nije u stanju da izgradi sopstvene savemene diskurse. Bivanje na poluperiferiji u kojoj je proizvodnja znanja privilegija malog broja intelektualaca/ki, primorava je da stekne široki uvid u polja kojima se bavi, što nije nužna odlika naučnika/ca u jezgru, koji su okupirani sopstvenim značajem kao proizvođačima/cama aktuelnih znanja, odnosno proizvodnjom hegemonih diskursa; b) ono što na prvi pogled izgleda kao nedostatak, možemo interpretirati kao povlašćeni položaj, koji autorki omogućava kritički stav.

Svetlana Slapšak njen rad određuje pojmom liberalni feminizam, jer je pokazala ,gde su problemi feminizma sa socijalizmom, marksizmom, i posebno fašizmom”, mada je jasno da je „reč o liberalnom umu, najbližem Masarykovim ranim idejama”, ona „ni prema jednoj od pomenutih ideologija ne pokazuje netolerantnost” (Slapšak 2004: 155).

U eseju „O feminizmu” autorka feminizam definiše „kao problem ženinih težnja na slobodno individualno razviće u opštečovečanskim sferama i za zaštitu pri vršenju generativnih funkcija" (Chlapec Đorđević 1935: 5). Na više mesta insistira na značaju individualizma, zalažući se za pravo ženskog subjekta da participira u univerzalizmu, zagovarajući i partikularizam interesa povezan sa reproduktivnom funkcijom. Tvrdi da feminizam ,u klici postoji od kad je žena, usled fiziološkog materinstva manje pokretljiva, ocenjena kao inferiorna i bačena u drugi red ljudskog društva" (Chlapec Đorđević 1935: 5), te pokazuje da naučno nije moguće opravdati ženinu potčinjenost. Za jugoslovensku i srpsku kulturu konstruisala je feminističku istoriju žena koja se odvija u (rasističkom) diskursu teorije modernizacije i govori o univerzalnom postupnom razvoju društava po stupnjevima, od primitivnijih (obojeni narodi) ka razvijenijim (bela rasa). Žrtva ovog razvoja bila je 
Žena potisnuta na margine i obespravljena, te prati njen položaj u Grčkoj, Rimu, u epohi pojavljivanja a zatim i pobede hrišćanstva, tokom Francuske revolucije, do početka 19. stoleća i nastajanja nacionalnih država, pa do socijalizma. Nakon što je istražila teze o biološkoj i intelektualnoj inferiornosti žena u medicinskim, psihoanalitičkim, kulturnim i pravnim tezama, a zatim ih odbacila, dokazuje da muški pol ne znači preimućstvo na ma kom polju ljudske delatnosti, kao što ženski pol nije nužno vezan za slabiju vrednost. Pol nema ni u negativnom ni u pozitivnom smislu, u opštečovečanskim oblastima, za posledicu izvesne fizičke, a pogotovu ne psihičke osobenosti. Zato kritikuje uređenje društva ,čija je polazna tačka seksualni dimorfizam”. Suština feminističkog pokreta je u ,reformi društva, u smeru podele rada i socijalnih dobara po individualnim svojstvima pojedinaca, a ne po polu" (Chlapec Đorđević 1935: 20), te pokazuje da su funkcije generativnih organa ,žarište, gde prolaze niti iz kojih se plete potčinjenost žene" (Chlapec Đorđević 1935: 23-24). U tekstu „Individualna psihologija Alfreda Adlera i njen značaj za feminizam", ističe da je Adler kritikovao Freuda i zalagao se za jednakost žena i muškaraca u javnom, privatnom i porodičnom životu. Po Adleru nema muških i ženskih osobina, jer ljudi nose osobine vrste „koja je u svome razvoju individualno, a ne polno diferencirana” (Chlapec Đorđević 1935: 95). Pisala je „Muškarac i žena nisu samo raznovrsni oni su u mnogim pogledima jednaki - oni su ljudi. Zato im se ne sme poziv dodeliti po funkcijama seksualnih organa" (Chlapec Đorđević 1935: 140). Ne sme se u muškarcu gledati ,predstavnik vrste, a u ženi predstavnik pola, ženka. U višim sferama života, nije glavni činilac pol, nego osobne sposobnosti pojedinaca. Žena i muškarac imaju razne pozive, a koji je od njih najsvetliji, to se ne može generalno odrediti” (Chlapec Đorđević 1935: 140). Pišući o Masarykovom feminizmu istakla je visoko shvatanje o seksualnom moralu, zbog čega on ,traži za ženu isto vaspitanje, ista prava, istu moralnu, socijalnu i ekonomsku slobodu kao za muškarca" (Chlapec Đorđević 1935: 102).

U Studijama i esejima o feminizmu - Feminizam u modernoj književnosti Chlapec Đorđević praktikuje feminističku književnu kritiku. Atanasijević ističe da njen rad predstavlja ,prvu, sigurno povučenu brazdu, u neispunjenoj oblasti naše feminističke književnosti” (Atanasijević 2008: 201). Prva je feministička književna kritičarka u srpskoj buržaskoj jugoslovenskoj kulturi. Ona analizira različite konstrukcije ženskih likova i ženskosti u književnosti, najviše u prozi. Kao i u esejima o položaju žene i diskursima 
koji ga definišu, pokazuje da je i književna proizvodnja bojno polje u kojem se konstruišu tipovi ženskosti kao pozitivni ili negativni modeli, zavisno od toga da li se aktiviraju emancipatorski, pregovarački ili konzervativni diskursi. Opisujući kako se autori/ke pozicioniraju u kulturi, objašnjava koje ideologije i diskurse aktiviraju, te od Egipta i Grčke, preko srednjeg veka stiže do savremenih primera. Novu ženu, navodi ona, uveli su u američku književnost autori poput George Egerton. Zapostavljanje žene u patrijarhalnom braku glavna je tema romana N. Mereditha i ističe da je u domovini „birth control” (kontrole rađanja) emancipacija žene koračala brzim tempom i našla moćnog odjeka u književnosti. U Francuskoj, gde se oduvek budno pratio problem erotike, za pravo žene na ljubav borila se Geogre Sand protestujući protiv konvencionalnosti ženinog položaja u društvu (Chlapec Đorđević 1935: 6). Pominje i Charlotte Bronte, George Eliot, Virginiju Woolf, skandinavske autorke, poput Klare Rafael, a o Ibsenu govori kao o propagatoru feminizma. Objašnjava da sovjetska književnost, ,ukoliko ne služi interesima komunističke stranke, produžujući tradicije ruske književnosti, daje isečke iz života žene, unesrećene često katastrofalnim događajima revolucije, ali obogaćene mogućnostima da dođe do socijalne samostalnosti” (Chlapec Đorđević 1935: 8). Češke autorke, poput Eliške Krásnohorske, hvali kao spisateljice velikih moralnih i književnih kvaliteta. Objašnjavajući da je za vreme Hitlerove vladavine zavladao antifeminizam, ističe da je u Nemačkoj pre rata feminizam bio snažan i da se pojavljivao i u književnosti. Pominje i jugoslovenske pisce B. Stankovića, F. Bevka, T. Seliškara, koji su opisali potčinjen i ropski položaj ženskog pola, te nastavlja:

Svetski rat i razni socijalni pokreti koji su velikim delom nastali kao njegova posledica, ubrzali su socijalnu asimilaciju polova čime se nametnuo književnosti feministički problem u sve užoj povezanosti za život. Izjednačujući pojedince i staleže, kultura stvara razne narodne i međunarodne tipove, čija vrednost prelazi državne granice. Svaka književnost nosi naravno obeležje svoje bliske sredine i obeležje života koji se neposredno oko nje vodi, ali se u njoj stvaraju i ličnosti opšte čovečanskog značaja. Zato ćemo videti da takoreći književnosti svih naroda, u različitom intenzitetu i sa posebnih, često šta više divergentnih stanovišta, donose izražaje nove žene. Feminizam dobija u kulturnim emancipacijama društva odgovarajuća mesta (Chlapec Đorđević 1935: 12).

Objašnjavajući odnos univerzalno-partikularno (ili lokalno-internacionalno/globalno), ona pokazuje kako uspostavljeni hegemoni društveni 
procesi deluju u različitim lokalnim kontekstima. S obzirom na globalne procese modernizacije, lokalne sredine generišu svojstvene oblike modernosti, koji se realizuju glokalno, kao mešavina globalnog (univerzalnog) i lokalnog (partikularnog). Rezimirajući kako se moderna književnost globalno promenila u različitim lokalnim kontekstima u odnosu na raniju, zaključuje da sve više pokazuje ,napore ljudskog društva da omogući odvajanje seksualnih odnosa od reprodukcije" (Chlapec Đorđević 1935: 18). Romani pokazuju kako žena prolazi kroz ljubav i romantične avanture neoštećena, te su moralne refleksije i sentimentalne tužaljke o „sramoti” i ,grehu” otpale. Manje je tupih i preosetljivih žena koje su „uz muškarca animalno pribljubljene", jer su nesposobne da se snađu u životu, a nestanak takvih likova je u interesu žena. Književnost, posebno proza, konstruiše modele ženskosti, ona ima performativnu moć, jer kroz znanje koje donose, pripovesti nadziru. Ono što jesmo postajemo nizom identifikacija, a roman je snažno sredstvo za internalizaciju društvenih normi (Culler 2001: 108) na šta nam ukazuju interpretacije Chlapec Đorđević. Moderna književnost dovodi u pitanje dvostruki standard protiv kojeg su se feministkinje borile, te je sve više ženskih likova u čisto fizičkom naslađivanju u ljubavi, bez moralne osude, kao što je nekad bio slučaj samo sa muškim likovima. Puno je i likova žena koje nisu ni mlade ni lepe, ali nisu izvrgnute ruglu.

\section{Jela Spiridonović-Savić: Spiritualnost, ženska emancipacija/podređenost i povratak redu}

U radu Jele Spiridonović-Savić zanimaće me tri tematska okvira: 1) koncepti društvenosti, koji obuhvataju pitanje religioznosti, odnos prema paru individualno-kolektivno i pojam odgovornosti; 2) koncepti ženskosti u rasponu od emancipacijskih do patrijarhalnih i 3) koncepti umetnosti, jer na osnovu njenih eksplicitnih stavova autorku možemo odrediti kao antimodernističku modernistkinju, u smislu umetničke ideologije „povratka redu”.

Knjiga Susreti obuhvata eseje iz 30-ih godina 20. stoleća. Mnogi stavovi mogu se uklopiti u koncept antimodernog modernizma (Ramazani 2007: 210-211), te dominantne kulturalne pozicije između dva svetska rata. U politički indikativnom eseju „Religiozno osećanje i sadašnjica” iskazuje holističko stanovište, tipično za prvu polovinu 20. stoleća, da religije ne mogu 
postojati bez perspektive večnog trajanja i smisla celine. Kritikujući crkvu, jer želi da vlada dušama i udaljava se od duha hrišćanstva, objašnjava: „Divan primer jaza koji postoji između božanskog Hristovog učenja i sprovođenja tih učenja kroz crkvu, dao nam je ruski genijalni i najspiritualniji majstor Dostojevski u svome Velikom inkvizotoru" (Spiridonović-Savić 1944: 14). Poziva se i na Counta Kalegrija. Kalegri je osnovao Panevropsku uniju, kao način da se Evropa sačuva od svetske hegemonije boljševičke Rusije (Cudenhove-Kalegri 1931: 6). Cilj organizacije je bilo jedinstvo hrišćanske Evrope, zalaganje za etnički heterogenu i inkluzivnu ideju evropske nacije zasnovanu na zajedničkoj kulturi (Cudenhove-Kalegri 1931: 14-15). Dok je komunistička partija osuđivala klasno ugnjetavanje, te religiju smatrala „opijumom za narod”, desni socijalizam Spiridonović-Savić (i panevropskog pokreta) zasniva se na religioznosti kao temelju društvenosti i na socijalnoj pravdi. Ocenivši da je period u kojem živi ,jedan od najnereligioznijih”, pod nereligioznošću misli na „stanje duše koja vidi život pod uglom najgrubljeg materijalizma" (Spiridonović-Savić 1944: 15-16). Kritika individualizma i kritika materijalizma su povezane. Pozivajući se na Dostojevskog zaključuje da je potrebno ,razbiti ljusku uske ljudske individualnosti i ući putem ljubavi (koja vezuje vremensko sa večnim) u univerzalno" (Spiridonović-Savić 1944: 22). Eliotovskim terminima izraženo, diskurs Spiridonović-Savić deluje u okviru ideje ,jedinstva evropske civilizacije" (Eliot 1951, 1982). Ali postavlja se pitanje kako u taj narativ uklopiti malu, perifernu srpsku pravoslavnu evropsku kulturu. I ovde ću upotrebiti pojam glokalnosti, jer autorka jedan evropski (globalni) model implementira u lokalni kontekst. Da bi srpska pravoslavna jugoslovenska buržoaska kultura postala deo panevropskog koncepta ujedinjene hrišćanske Evrope, mora se pozvati na veliku rusku kulturu, koja joj daje legitimitet da postane deo hrišćanske Evrope. U tekstu Rekvijem pesniku Rilkeu opisuje kako Rilke putuje Evropom, a boravak u Rusiji pothranjuje njegovu naklonost prema mistici, ali nigde ne pominje Sovjetski Savez, kao da u tom trenutku ne postoji komunistička sovjetska Rusija.

Njen svetosavski ep Pergamenti interpretiraću kao stvaranje savremene pravoslavne religiozne književnosti, čemu pravoslavna religiozna matrica nije bila uvek sklona ${ }^{2}$. Pišuči ep, srpsku pravoslavnu kulturu simbolički

2 Iako je ovaj stav izrečen kao univerzalan, o njemu se može raspravljati, i može se kontekstualizovati od kulture do kulture. 
uključuje u zajednicu evropskih naroda i lokalnoj maloj poluperifernoj pravoslavnoj kulturi i njenom nasleđu dodeljuje univerzalni status, kakav imaju tradicije centralnih kultura. Konstantinović navodi da joj je u nacističkom časopisu „Srpski narod” anonimni prikazivač zamerio to što je u potpunosti podređena srednjovekovnom zapadnom misticizmu, zanemarivši postojanje „srpske mistike” (Konstantinović 1975: 349).

Spiridonović-Savić se kretala između diskursa emancipacije žena u javnoj sferi i diskursa pokoravanja patrijarhalnom poretku kroz reproduktivnu funkciju i to je prisutno u njenim esejima, poeziji i prozi ${ }^{3}$. Odbacujući načelno individualizam modernosti, zagovara antimodernizam. Ipak, individualnost ističe kao lični kvalitet, sposobnost i talenat, jer su važni za emancipaciju žena u javnoj sferi, a istovremeno zastupa biološki esencijalizam u neophodnosti žrtvovanja žene kao majke, jer je ta njena dužnost najveća sreća, pri čemu treba napomenuti da autorka nije imala dece. U tekstu o Rilkeu ističe tradicionalnu reprezentaciju žena kao mitskih i alegorijskih eteričnih bića, čime se istorijska i pluralna žena transformiše u histeričnu i singularnu Ženu. Postupak je povezan sa „religioznom/spiritualnom transcendencijom, tipičnom modernističkom praksom, njenim anti-sekularnim rešenjima" (DuPlessis 1990: 152).

U „Značaju unutrašnjeg života za razvoj ličnosti” ona piše da je savremena žena na intelektualnom polju izjednačena sa muškarcem, ali se postavlja pitanje ,da li postoji njen čisto ženski prilog na polju kulturnog razvoja?” i zaključuje da postoji. Priroda „traži od žene jednu veliku žrtvu: materinstvo, a s druge strane ju je učinila i bogatom da je ta žrtva njena, u stvari i ženina: najveća sreća" (Spiridonović-Savić 1944: 171). Imajući u vidu emancipatorske aspekte poezije Spiridonović-Savić, Chlapec Đorđević je pisala da njeni stihovi pokazuju da ,pušta se u život na sopstvenu odgovornost, svesna lepote i opasnosti koje joj on pruža" (Chlapec Đorđević 1937: 14). Ali Konstantinović će 1975. kritikovati njen desni feminizam. Ideal za koji se zalaže je, po njemu, ,ideal savršene skrušenosti sopstvenog Ja, ideal blaženstva kroz žrtvu ili ideal materinstva koje je davanje bez uzimanja ili vrhunska oslobođenost od sopstvenog Ja, najviše mogućan oblik misticizma" (Konstantinović 1975: 258).

3 U tekstu M. Koch (2009) nalazimo tezu da se u esejima, poeziji i prozi ove autorke realizuje jedan poseban i jasan projekt. 
Nakon što se 90-ih godina 20. stoleća socijalistička Jugoslavija raspala, u Srbiju, kao i u celu bivšu Istočnu Evropu ponovo stiže feminizam, te su feminističke autorke reinterpretirale rad ove književnice. U tekstu Na rubovima, ka središtu poezije: Jela Spiridonović-Savić (Đurić 1996: 177-182) pozitivno sam ocenila njenu mistiku, s aspekta depolitizovanog feminističkog diskursa, u kojem kao postkomunistički subjekt vrednujem spiritualnost kao univerzalistički koncept, cenzurisan iz socijalističkog društva, ali ga ne vezujem za ideju nacionalnog identiteta. Jovana Reba Kalauzov u knjizi Misticizam Jele Spiridonović-Savić (Reba Kalauzov 2011) sa sličnih pozicija reafirmiše rad autorke, ističući značaj spiritualnosti u vezi sa savremenom (re)konstrukcijom srpskog postsocijalističkog nacionalnog identiteta kada, kao i u ostalim postsocijalističkim zemljama, religija dobija središnje mesto.

U tekstu o Rilkeu Spiridonović-Savić (anti)modernistički objašnjava da umetnost, poput religije, ima svoj poseban svet. Ona živi od elementarnih sadržaja stvarnosti,

ali umetnošću postaje tek onda, kada tim sadržajima dâ formu, uslovljenu umetnikovim pogledom na svet, njegovim osećanjem, njegovim specifičnim shvatanjima, i to je onda jedan sasvim nov svet, s onu stranu sasvim je nešto drugo, no prostor realnosti. (...) Jer kad bi umetnost bila fotografski duplikat stvarnosti, ona bi onda, kao takva, bila izlišna (Spiridonović-Savić 1944: 24).

Po Konstantinoviću, Spiridonović-Savić je, kao i drugi pesnici/kinje njene generacije, žudila za ekstatičkim stanjem. Ta žudnja kod nje ,dobija religijsko značenje" (Konstantinović 1975: 343). Ona pokušava ritmom da dočara ekstazu, ali je odvojen od reči, te jezgro pesme ,ostaje u zatečenim normama zatečene svesti" (Konstantinović 1975: 345). Kod pesnika te generacije, ideal dinamizma se traži usred fosilizovane strukture zatečene svesti. Konstantinovićevu kritiku možemo shvatiti u kontekstu njegove pozicioniranosti u socijalističkoj srpskoj jugoslovenskoj kulturi. Kao zastupnik socijalističkog modernizma, oštro je kritikovao ideju ,povratka redu”, kao društveno i umetnički konzervativnu i nazadnu. Po Mišku Šuvakoviću, povratak redu je proces koji se odvijao pre i nakon Prvog svetskog rata. U njemu se očituje kriza radikalnog modernizma i avangarde, ali i reakcija „dominantne umjereno modernističke kulture na avangardne prakse” (Šuvaković 2005: 503). 


\section{Zaključak}

Raspravljajući o savremenim diskursima modernizma i feminizma, J. Chlapec Đorđević sam kao predstavnicu levo orijentisanog buržoaskog feminizma masarikovskog tipa suprotstavila J. Spiridonović-Savić, predstavnici desno orijentisanog buržoaskog feminizma ${ }^{4}$. Pokazujem kako su njihovi koncepti modernizma i feminizma antagonistički postavljeni, jer referiraju na nauku i svetovnost u slučaju Chlapec Đorđević ili na religiju i misticizam u slučaju Spiridonović Savić.

Mom tekstu se može kritički pristupiti sa argumentum da je reč o autokolonijalizmu koji se mogao iščitati iz moje upotrebe interpretativnog modela P. Casanove, izvedenog iz svetskog sistema Immanuela Walersteina. Nasuprot autokolonijalizmu je koncept alternativne modernosti, kojim se zagovara teza da su kolonizovane zemlje generisale posebne tipove modernosti, koje je zapadni hegemoni koncept isključivao kao netipične i beznačajne. Koncept alternativne modernosti je bitan jer je proširio značenja pojma modernosti. Za mene je još značajnija globalizacija modernosti i feminizma, koja omogućava kulturama koje nazivamo malim da budu postavljene na globalnu mapu i tako postanu globalno vidljive. I zaista, posmatrati manje kulture kao poluperiferne, koje uvek kasne za prvim zemljama, što ja činim, može se shvatiti kao autokolonizacija. Ali u ovom argumentu se zaboravlja da i sama činjenica da posežemo za pojmovima poput modernizma i feminizma, i fenomenima koje oni označavaju jeste apriorno vrsta autokolonijalizacije.

Kultura je uvek bojno polje, pisali su autori/autorke britanskih kulturalnih studija. U svakoj kulturi se vide borbe za postavljanje hegemonih modela. Pitanje šta je modernost i šta je feminizam ili da li će ti pojmovi imati ili neće ulogu u lokalnim kulturama, zavisi od političkih i ekonomskih odnosa moći koje najčešće imaju uticaj na hegemone koncepte lokalne kulture. Zalagati se za autohtone/alternativne modernosti koje lokalne kulture mogu generisati - zar to nije indigenizacija i autokolonizacija, tj. zatvaranje u lokalne okvire? Ili zar to nije jedan od trenutno hegemono globalno generisanih diskursa kroz koje neke kulture mogu sebe definisati u lokalnim

${ }^{4}$ Pojmovi levi i desni feminizam se možda mogu podvrgnuti kritici ili preispitati, ali to ostavljam nekim budućim intepertacijama. 
borbama moći koje se tiču i globalnog pozicioniranja date kulture? I još jedan termin bitan u kulturalnim studijama: teorija je, kao i celokupna kulturalna proizvodnja uvek zasnovana na skupu političkih kontradikcija i antagonizama.

\section{Literatura}

Atanasijević K., 2008, Etika feminizma, izbor, priređivanje i predgovor Lj. Vuletić, Beograd, <http://www.helsinki.org.rs/serbian/doc/Ogledi11.pdf>, 14.02.2014.

Bhambra G.K., 2007, Rethinking Modernity - Postcolonialism and the Sociological Imagination, Hampshire.

Blagojević M., 2009, Knowledge Production at the Semiperiphery - A Gender Perspective, Beograd.

Casanova P., 2004, The World Republic of Letters, Cambridge.

Chlapec Đorđević J., 1935, Studije i eseji o feminizmu, Beograd.

Chlapec Đorđević J., 1937, Studije i eseji o feminizmu II: Feminizam u modernoj književnosti, Beograd.

Cudenhove-Kalegri R.N., 1931, Panevropa: Pitanja i odgovori, Beograd.

Culler J., 2001, Književna teorija - Vrlo kratak uvod, Zagreb.

DuPlessis R.B., 1990, The Pink Guitar - Writing as Feminist Practice, London, New York.

Đurić D., 1996, Na rubovima, ka središtu poezije: Jela Spiridonović-Savić, „ProFemina" br. 8, str. 177-182.

Đurić D., 2011, Izvođenje novog teorijskog okvira za čitanje poezije Danice Marković $u$ diskursima srpske istorije književnosti, „Knjiženstvo. Časopis za studije književnosti, roda i kulture" br. 1, <http://www.knjizenstvo.rs/magazine.php?text=9>, 14.02.2014.

Đurić D., 2013, Metodološki kosmopolitizam i proučavanje književnosti, „Beležnica” br. 26, str. 181-185.

Eliot T.S., 1951, The Unity of European Culture, Kiel.

Eliot T.S., 1982, The Idea of Christian Society and Other Writings, London.

Juvan M., 2009, Svetovni literarni sistem, „Primerjalna književnost” 2, str. 181-212.

Koch M., 2009, Od afirmacije do zaborava: Anđelija Lazarević, Milica Janković i Jela Spiridonović-Savić u Srpskoj književnoj zadruzi i u srpskom književnom kanonu, u: Mesto pripovetke u srpskoj književnosti. Dositej Obradović i Evropa. Naučni sastanak slavista u Vukove dane, ur. D. Mršević-Radović et al., str. 209-220. 
Koch M., 2012, Kada sazremo kao kultura. Stvaralaštvo srpskih spisateljica na početku XX veka (kanon - rod-žanr), prev. J. Jović, Beograd.

Konstantinović Z., 1975, Nevesta šumskog drveća Jela Spiridonović Savić, „Treći program Radio Beograda" br. 27, str. 324-350.

Ramazani J., 2007, Caliban's modernity: postcolonial poetry of Africa, South Asia and the Caribbean, u: A. Davis, L.M. Jankins, The Cambridge Companion to Modernist Poetry, Cambridge, str. 207-221.

Reba Kulauzov J., 2011, Misticizam Jele Spiridonović Savić, Beograd.

Slapšak S., 2004, Julka Hlapec Đorđević. Jedno dopisivanje: odgovor posle sedamdeset godina, u: J. Hlapec Đorđević, Jedno dopisivanje - fragmenti romana, Beograd, str. 153-172.

Spiridonović-Savić J., 1944, Susreti, Beograd.

Šuvaković M., 2005, Pojmovnik suvremene umjetnosti, Zagreb. 